\title{
Gry komputerowe jako nowoczesny rodzaj rozrywki wspomagający rehabilitację, edu- kację oraz aktywizację w społeczeństwie osób z niepełnosprawnością
}

\section{Computer games as a modern type of entertainment which provide rehabilitation, education and activation in society for persons with disabilities}

\begin{abstract}
Streszczenie:
Artykuł zwraca uwagę na problem dotyczący dostosowania gier komputerowych pod potrzeby osób z niepełnosprawnością. Zostały w nim również opisane trudności, przeszkody z jakimi muszą się one borykać. W rezultacie zostaje przedstawionych kilka gier, które mogą być wykorzystywane przez osoby słabowidzące, niewidome, niedosłyszące, głuche oraz nie dysponujące pełną ruchowością rąk. Ukazane zostało praktyczne i pozytywne wykorzystanie gier komputerowych dla zdrowia osób z niepełnosprawnością. Praca podkreśla istotność dostosowania nowoczesnego rodzaju rozrywki do jak największego rodzaju ograniczeń osób niepełnosprawnych.
\end{abstract}




\begin{abstract}
:
Article focuses ON the problem of adapting video games for the needs of people with disabilities. It also describes difficulties, obstacles with which they must contend. As the result it shows several games that can be used by the visually impaired, blind, hard of hearing, deaf, and not possessing full hands movement. It presents is a practical and positive use of computer games to help people with disabilities. The work emphasizes the importance of adapting to the modern type of entertainment for people with any disabilities.
\end{abstract}

Słowa kluczowe: gry komputerowe dostosowane do osób z niepełnosprawnością, nowoczesny rodzaj rozrywki dla osób niepełnosprawnych, gry komputerowe służące rehabilitacji.

Keywords: computer games adapted for people with disabilities, the modern type of entertainment for people with disabilities, games for rehabilitation.

\title{
1. Wprowadzenie
}

Gry komputerowe stanowią jedną z najbardziej atrakcyjnych i popularnych rozrywek. Niezależnie od tego czy są to gry pecetowe, konsolowe, czy też gry na urządzenia mobilne. Są sposobem motywacji do nauki i dalszego kształcenia się, wzmacniają szybkość reakcji i poprawiają koncentrację. ${ }^{29}$

Dla wielu osób spoza grona miłośników gier komputerowych, stanowią one jedynie bezwartościową, skierowaną głównie do dzieci rozrywkę, która odciąga od realnych problemów i może uzależniać równie silnie jak alkohol lub inne używki. Tymczasem możliwości praktycznego, pozytywnego wykorzystania komputerowych gier tak

\footnotetext{
${ }^{29}$ Źródło: http://dziendobry.tvn.pl/wideo,2064,n/gry-komputerowe-pomoga-
} niepelnosprawnym,48476.html (stan na dzień: 06.12.2016 r.) 
naprawdę zależą tylko od pomysłowości ich użytkowników. Przykładem tego może być używanie gier komputerowych przez instruktorów terapii zajęciowej, którzy pracują z ludźmi o umiarkowanym i znacznym stopniu niepełnosprawności ${ }^{30}$. Gry pomagają w rewalidacji zarówno dzieciom, młodzieży jak i dorosłym. Ta forma rozrywki stworzona w celu rehabilitacji ON powinna być bardzo prosta, zarówno jeśli chodzi o zasady, jak i interfejs. ${ }^{31}$ Jednak mimo spełnienia powyższych cech osoby $\mathrm{z}$ niepełnosprawnością napotykają pewne trudności podczas korzystania $\mathrm{z} \mathrm{w} / \mathrm{w}$ oprogramowania. Przeszkody te oraz rozwiązania pomagające sprostać tym barierom, a także liczne przykłady gier wspomagające leczenie ON zostaną omówione w dalszej części artykułu.

\section{Trudności napotykane przez ON podczas korzystania z oprogramowania.}

Korzystanie z gier komputerowych piętrzy poważne przeszkody. Jeśli ktoś nie dysponuje pełną sprawnością obu rąk, będzie miał kłopoty z większością gier konsolowych i niejedną pecetową. Wystarczy przypomnieć sobie jakie problemy pojawiały się w sytuacji, kiedy np. mieliśmy rękę w gipsie lub wybity palec. Osoby, które mają kłopot $\mathrm{z}$ widzeniem barw mogą mieć problemy z rozróżnieniem przeciwników od sojuszników lub kolorowych wskaźników na minimapce. A co z osobą pozbawioną zmysłu słuchu? W wielu grach sygnały akustyczne stanowią istotną część informacji.

\footnotetext{
${ }^{30}$ Źródło: http://www.inter.uni.lodz.pl/index.php/media/209-wirtualne-gry-realnekorzyci (stan na dzień: 07.12.2016 r.)

31Źródło: http://www.psxextreme.info/topic/109036-gry-dla-os\%C3\%B3bniepe\%C5\%82nosprawnych/ (stan na dzień: 07.12.2016 r.)
} 


\section{Zwalczanie utrudnień związanych $\mathrm{z}$ używaniem gier komputerowych}

W tej części artykułu zostaną przedstawione działania mające na celu „zlikwidowanie” bądź redukcję utrudnień z jakimi na co dzień borykają się ON podczas korzystania z gier komputerowych.

Wyzwania jakie pojawiają się przed graczami niepełnosprawnymi są bardzo zróżnicowane w zależności od rodzaju ich ograniczeń. Upośledzenie wzroku, słuchu, ruchomości, refleksu czy innych cech może przyjąć bardzo różne formy. Autorom gier komputerowych trudno jest znaleźć uniwersalne rozwiązanie wspomagające ON. Każdy może cierpieć na inną przypadłość. Poszczególne choroby wymagają więc innych, odległych środków. Co więc zrobić w takiej sytuacji? $\mathrm{Z}$ pomocą przychodzą takie projekty, jak Includification czy Game Accessibility Guidelines. Pierwszy z nich, dostępny w formie ilustrowanego PDF-a, powstał dzięki fundacji AbleGamers, której celem jest wspomaganie graczy niepełnosprawnych, m.in. poprzez uświadamianie i edukowanie ${ }^{32}$. Organizacja non-profit pomogła niezliczonej ilości graczom niepełnosprawnych wrócić do korzystania z gier po urazie bądź zagrać w gry po raz pierwszy mimo niepełnosprawności ${ }^{33}$. Fundacja ta przyznaje również co roku wyróżnienia grom najbardziej przyjaznym osobom niepełnosprawnym. Drugi projekt powstał jako wspólny wysiłek naukowców i przedstawicieli branży gier komputerowej, żeby udostępnić materiały źródłowe, z których będą mogli skorzystać twórcy gier, swego rodzaju ściągawkę z listą gotowych do wdrożenia rozwiązań.

Oba projekty przedstawiają propozycje ułatwień, które pozwolą osobom z rozmaitymi ograniczeniami cieszyć się grami. Proponowane rozwiązania są podzielone na trzy kategorie: trywialnie łatwe do zaimplementowania, średnio skomplikowane i trudne, które wy-

\footnotetext{
32 Źródło: http://www.kson.pl/gazeta/na-swiecie-i-w-kraju/611-gry-komputerowedla-niepelnosprawnych (stan na dzień: 08.12.2016 r.)

33 Źródło http://www.includification.com/ (stan na dzień: 08.12.2016 r.)
} 
magają większych nakładów pracy. Każdy z tych projektów poświęca ponadto trochę miejsca na wytłumaczenie $\mathrm{z}$ jakimi wyzwaniami zmagają się osoby niepełnosprawne podczas gry, a także dlaczego warto im pomóc. Pomijając argumenty natury etycznej i ogólnoludzkiej, istnieją też bardzo konkretne przesłanki ekonomiczne - po prostu warto zagospodarować tę pulę potencjalnych klientów ${ }^{34}$.

Teraz zostanie przedstawionych kilka przykładów gier dostosowanych pod potrzeby osób z niepełnosprawnością. Gry zostały stworzone według Includification (praktycznego przewodnika, w którym zamieszczone są wskazówki dotyczące stworzenia gry dostępnej dla wszystkich) :

- Pierwszą z nich jest RockSmash. Jest to rodzaj gry walczącej/bitewnej. Polega ona na Rozbiciu czego tylko chcesz za pomocą myszki, standardowej klawiatury lub włącz opcję automatycznego młotka i baw się posługując się zaledwie trzema przyciskami. W grze można zmienić kontrast, aby w Rocksmash wszystko łatwiej zobaczyć. Gra pozwala również na dostosowania szybkości gry. Jest możliwość powiązania każdego klawisza. Obecnie ta gra posiada $V$ generacji.

- Drugi przykład, który zostanie przybliżony to gra Pokemon Sun and Moon. Rodzaj gry przygodowej. Aby korzystać z gry wystarczy obsługa trzech przycisków Q, T oraz E. Czasami wymagane jest od gracza przyciśniecie klawisza A, w celu wymieszania składników w grze. ${ }^{35}$

\footnotetext{
${ }^{34}$ Źródło: http://www.kson.pl/gazeta/na-swiecie-i-w-kraju/611-gry-komputerowedla-niepelnosprawnych (stan na dzień: 08.12.2016 r.)

35 Źródło: http://www.unstoppablegamer.com/pokemon-sun-and-moon/ (stan na dzień: 09.12.2016 r.) (tłumaczenie własne)
} 


\section{Rys. 1. Wizualizacja gry Pokemon Sun and Moon}

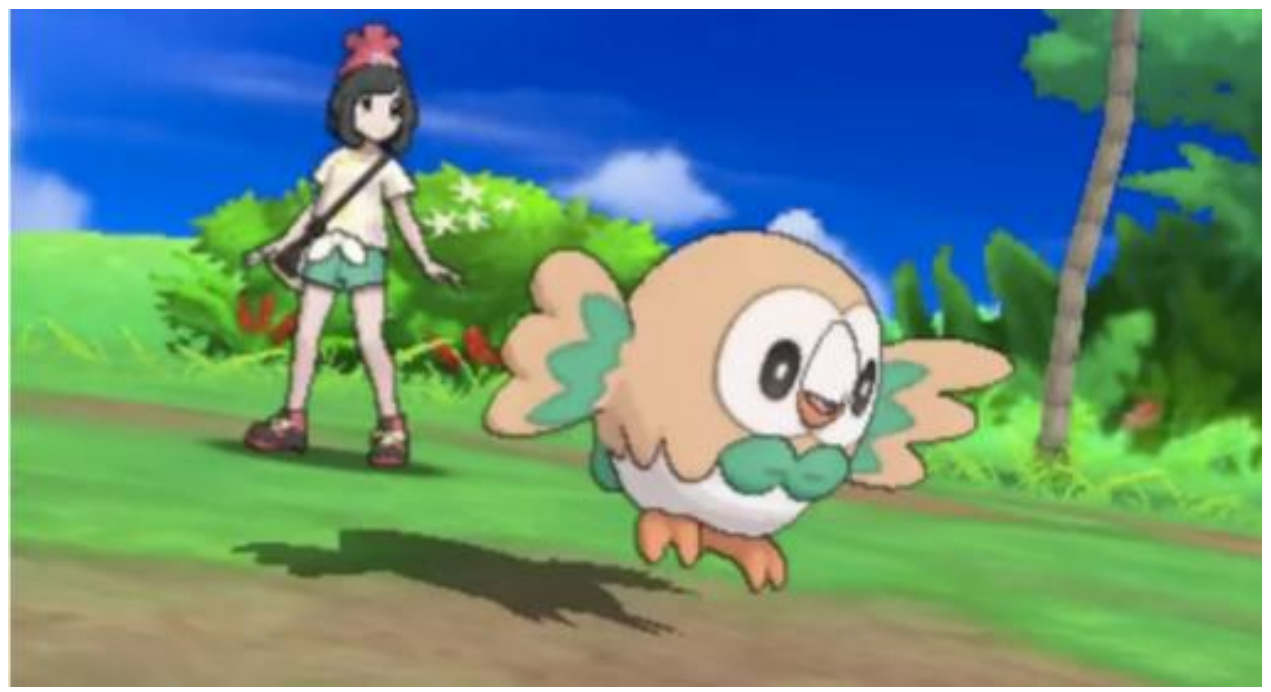

Źródło: http://www.unstoppablegamer.com/pokemon-sun-and-moon/ (stan na dzień: 09.12.2016 r.)

Ciekawostką jest to, że na stronie AbleGamer jest możliwość zaznaczenia opcji dotyczących wyszukiwanych przez nas gier.

Możemy wybrać jedną z następujących opcji:

- Jestem graczem z jedną ręką,

- Jestem głuchym graczem,

- Jestem daltonistą. ${ }^{36}$

36 Źródło: http://www.unstoppablegamer.com/tag/one-handed/ (stan na dzień: 08.12.2016 r.) 
Rys. 2. Menu strony instytucji AbleGamers.

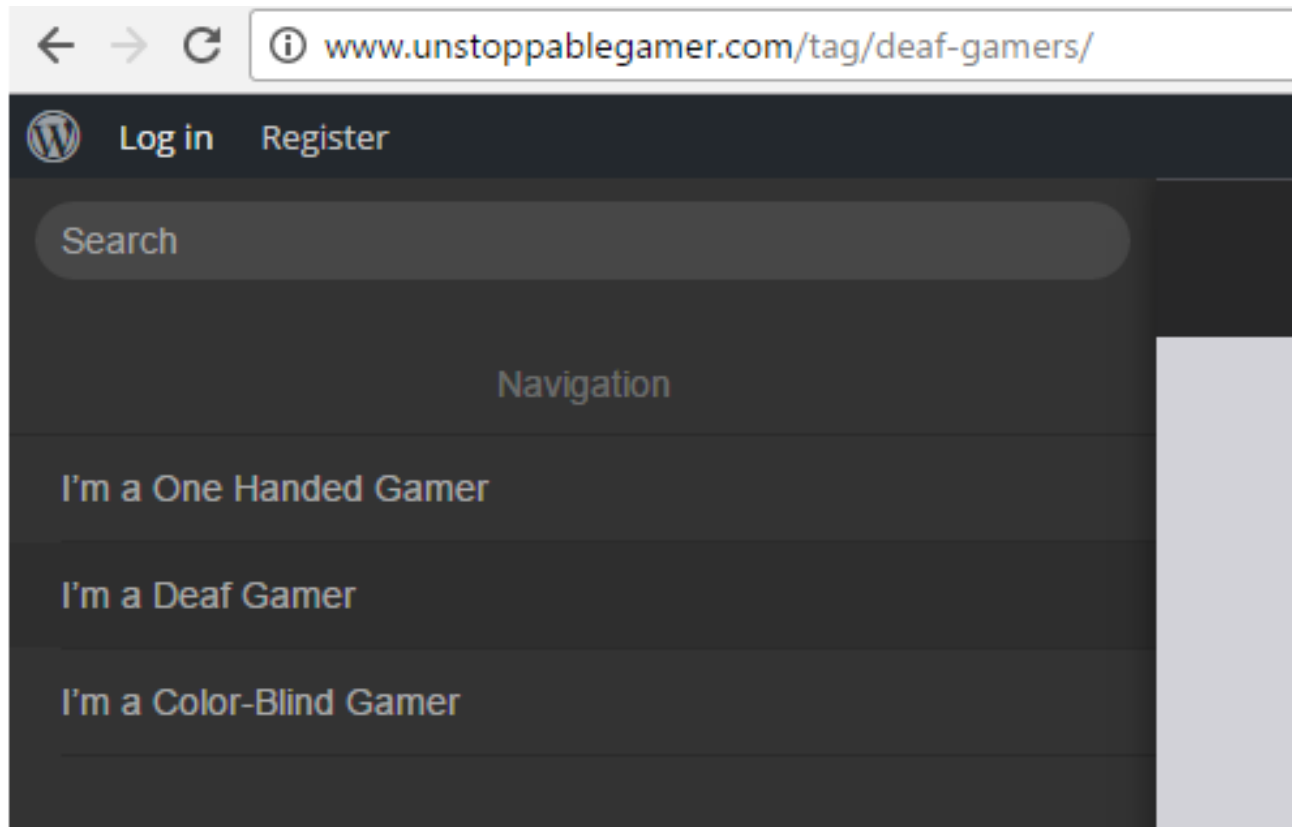

Źródło: opracowanie własne

Wyżej wspomniane gry są głównie skupione na dostarczeniu rozrywki osobie z niepełnosprawnością. Teraz przejdę do kilku gier, które wspomagają leczenie, wpływają na szybszą, efektywniejszą rehabilitację.

\section{Gry dla osób niewidomych.}

Osoby niewidome i niedowidzące mogą w coraz większym stopniu bawić się grami komputerowymi, dzięki rosnącej liczbie dostępnych gier dźwiękowych. Obecnie na rynku dostępnych jest około 50 tytułów i ok. trzy razy tyle programów darmowych. Tak jak gry graficzne, gry audio dostępne są w wielu odmianach: przygodówki, 
platformówki i wiele innych. Jednak zdaniem Kelly Sapergia, która recenzuje gry audio dla Radia ACB, pewne elementy są $w$ takich grach niezbędne. Najważniejsze są oczywiście wyraziste dźwięki, dzięki którym gracz w prosty sposób może zorientować się, gdzie się znajduje. Można to uzyskać poprzez różnorodną muzykę ambientową lub różne odgłosy kroków postaci sterowanej przez gracza w zależności od podłoża, na jakim się porusza. Ważne są także dialogi, które będą prowadziły gracza przez świat gry.

Jedną z pierwszych firm, które zaczęły tworzyć gry audio była amerykańska firma Bavisoft - do tej pory wypuściła na rynek trzy specjalne wydania dedykowane osobą pozbawionym zmysłu wzroku. Pomysłodawcą tworzenia gier dźwiękowych był właściciel firmy, który jest daltonistą i doświadczał wielu problemów, bawiąc się grami komputerowymi z powodu nieodpowiedniego kontrastu na ekranie. Wiele elementów było dla niego wręcz niewidocznych. Jednak aby stworzyć dobrą grę audio, należy w zupełnie nowatorski sposób podejść do jej tworzenia już na etapie programowania. Ostatnia gra stworzona przez firmę Bavisoft pt. "Chillingham" jest grą przgodową, której akcja rozgrywa się w nawiedzonej wiosce. Gracz musi rozwiązywać różne zagadki i jednocześnie bronić się przed atakami ze strony wampirów, wiedźm oraz wilkołaków. Skuteczna obrona przed tymi storami wymaga doskonałego zestawu głośników stereo lub bardzo dobrych słuchawek, aby móc w łatwy sposób zlokalizować napastników. ${ }^{37}$

Nie wszyscy jednak podzielają entuzjazm dotyczący świetlanej przyszłości gier opartych jedynie na dźwięku. Zdaniem Richarda Van Tola, komputery i konsole do gier są w zbyt dużym stopniu zorientowane na grafikę, by gry dźwiękowe mogły się przebić na rynku dla pełnosprawnych graczy. Dodatkową przeszkodą jest brak dobrej ja-

\footnotetext{
${ }^{37}$ Źródło: http://www.niepelnosprawni.pl/ledge/x/11474 (stan na dzień: 08.12.2016 r.)
} 
kości silników audio. Obecnie stosowane silniki 3D wykorzystują jedynie dwie płaszczyzny - gracz może usłyszeć dźwięki jedynie przed sobą lub za sobą, ale nie z góry lub z dołu.

\section{Gry komputerowe ułatwiające rehabilitację osób z nie- pełnosprawnością.}

Gry wideo coraz częściej znajdują również zastosowanie w procesie leczenia. Wykorzystuje się je m.in. w terapii osób cierpiących na Alzheimera. Elektroniczne programy zmuszają pacjentów do wysiłku umysłowego i logicznego myślenia, co pomaga niekiedy zastopować postępy choroby, a czasami nawet odrobinę zmniejszyć jej objawy. Komputerowe gry używane są także przy rehabilitacji osób z niepełnosprawnością fizyczną, które dzięki nim mogą ćwiczyć swoją koordynację ruchową. Dodatkową zaletą takiej terapii jest fakt, iż gry odciągają uwagę od dolegliwości, motywują go do ćwiczeń i przyśpieszają tym samym cały proces leczenia. ${ }^{38}$

Mówiąc o rehabilitacji przy pomocy gier komputerowych warto wyjaśnić to pojęcie:

Rehabilitacja grami wideo, znana jest również jako rehabilitacja gier. Jest procesem, który za pomocą konsol do gier wideo oraz metodologii do namierzania poprawia słabości fizyczne i psychiczne w procesach terapeutycznych. Platformy, które posiadają sterowanie ruchem to Nintendo Wii, Microsoft Xbox Kinect i Sony Eye Toy. Metodologie zostały zastosowane we wszystkich grupach wiekowych, od małego dziecka aż do podeszłego wieku. Na całym świecie zostały wykorzystane $\mathrm{w}$ wielu przypadkach od rehabilitacji po udarze mózgu, porażeniu mózgowym i innych zaburzeń neurologicznych. Użyte również zostały przy zapaleniu ścięgien i stwardnieniu rozsianym. Naukowcy promują taką technologię opartą o personalizację syste-

\footnotetext{
38 Źródło: http://www.inter.uni.lodz.pl/index.php/media/209-wirtualne-gry-realnekorzyci (stan na dzień: 08.12.2016 r.)
} 
mów gier dla pacjentów, co pozwala na dalsze zaangażowanie i interakcję. Dodatkowo, konsole do gier mają możliwość przechwytywania danych w czasie rzeczywistym i zapewniają natychmiastową informację zwrotną dla pacjentów korzystających z tych systemów. ${ }^{39}$ Do narzędzi, gier wspomagających leczenie ON zaliczamy:

- Trening z użyciem ManovoSpring polega na realizowaniu przez pacjenta zadań wyświetlanych na monitorze. Wirtualna rzeczywistość i formuła gry komputerowej wykazują wysoką skuteczność w rehabilitacji neurologicznej kończyn, pacjent jest bardziej zaangażowany $\mathrm{w}$ leczenie co skutkuje pozytywnymi efektami terapeutycznymi. ${ }^{40}$

- Mira jest platformą oprogramowania przeznaczona do fizjoterapii w postaci zabawy. Jest dogodna dla pacjentów po operacji lub urazie. System przetwarza istniejące fizyczne ćwiczenia terapeutyczne do gier wideo. Korzysta z zewnętrznego czujnika do śledzenia i oceny podatności pacjenta ${ }^{41}$.

39 Źródło: https://en.wikipedia.org/wiki/Video_game_rehabilitation (stan na dzień: 08.12.2016 r.) (tłumaczenie własne)

40 Źródło: https://www.youtube.com/watch?v=CCvBevd_Xvc (stan na dzień: 08.12 .2016 r.)

${ }^{41}$ Źródło: http://www.mirarehab.com/ (stan na dzień: 08.12.2016 r.) 
Rys. 3. Przedstawienie gry wideo i zewnętrznego czujnika do śledzenia i oceny podatności pacjenta.

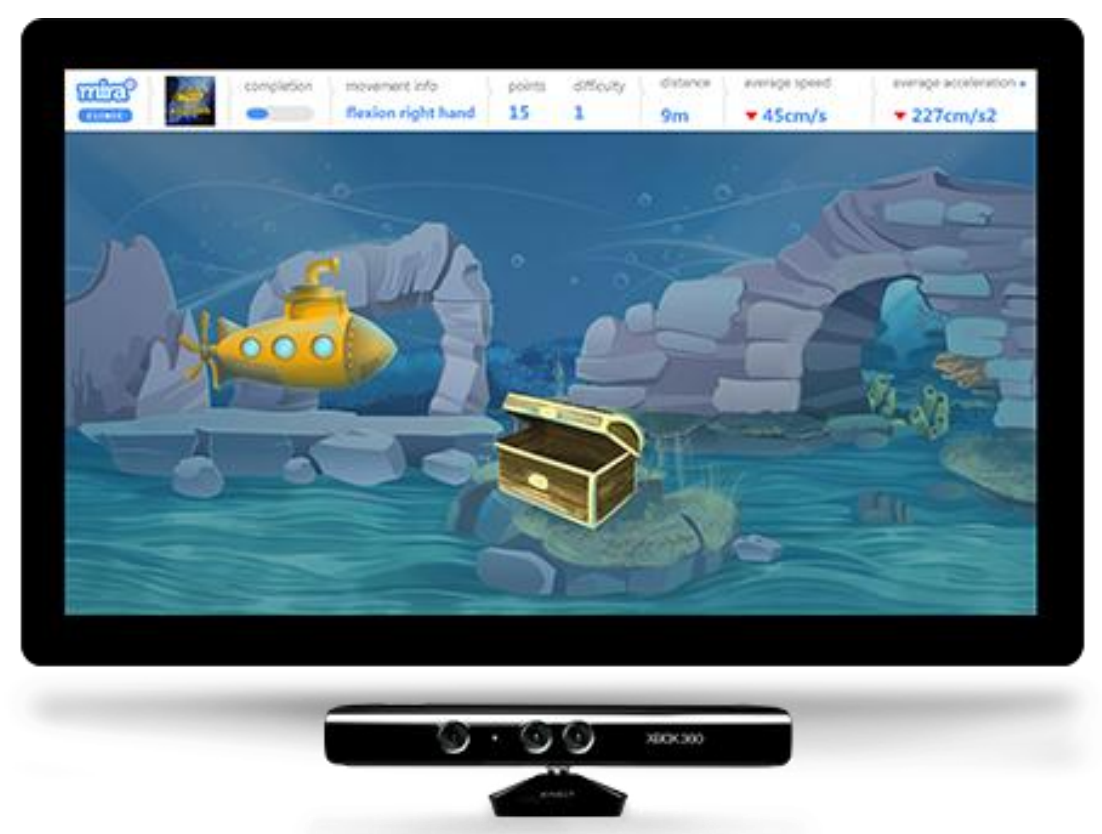

Źródło: http://www.mirarehab.com/ (stan na dzień: 08.12.2016 r.)

- VirtualRehab jest klinicznie potwierdzonym systemem rehabilitacyji fizycznej, który korzysta z technologii gier wideo i pozwala na monitorowanie postępu pacjentów $\mathrm{z}$ dowolnego miejsca na świecie.42 VirtualRehab 3.0 przeznaczony jest dla profesjonalnych terapeutów, którzy pracują $\mathrm{z}$ pacjentami. Pacjenci cierpią na skutek poważnych schorzeń neurologicznych. ${ }^{43}$

42 Źródło: http://www.virtualrehab.info/ (stan na dzień: 08.12.2016 r.)

43Źródło: https://www.youtube.com/watch?v=2XNX_tZHL2E (stan na dzień: 08.12 .2016 r.) 


\section{Gra mobilna dla osób z niepełnosprawnością}

\section{Rys. 4. Wizualizacja gry na smartfona dla ON}

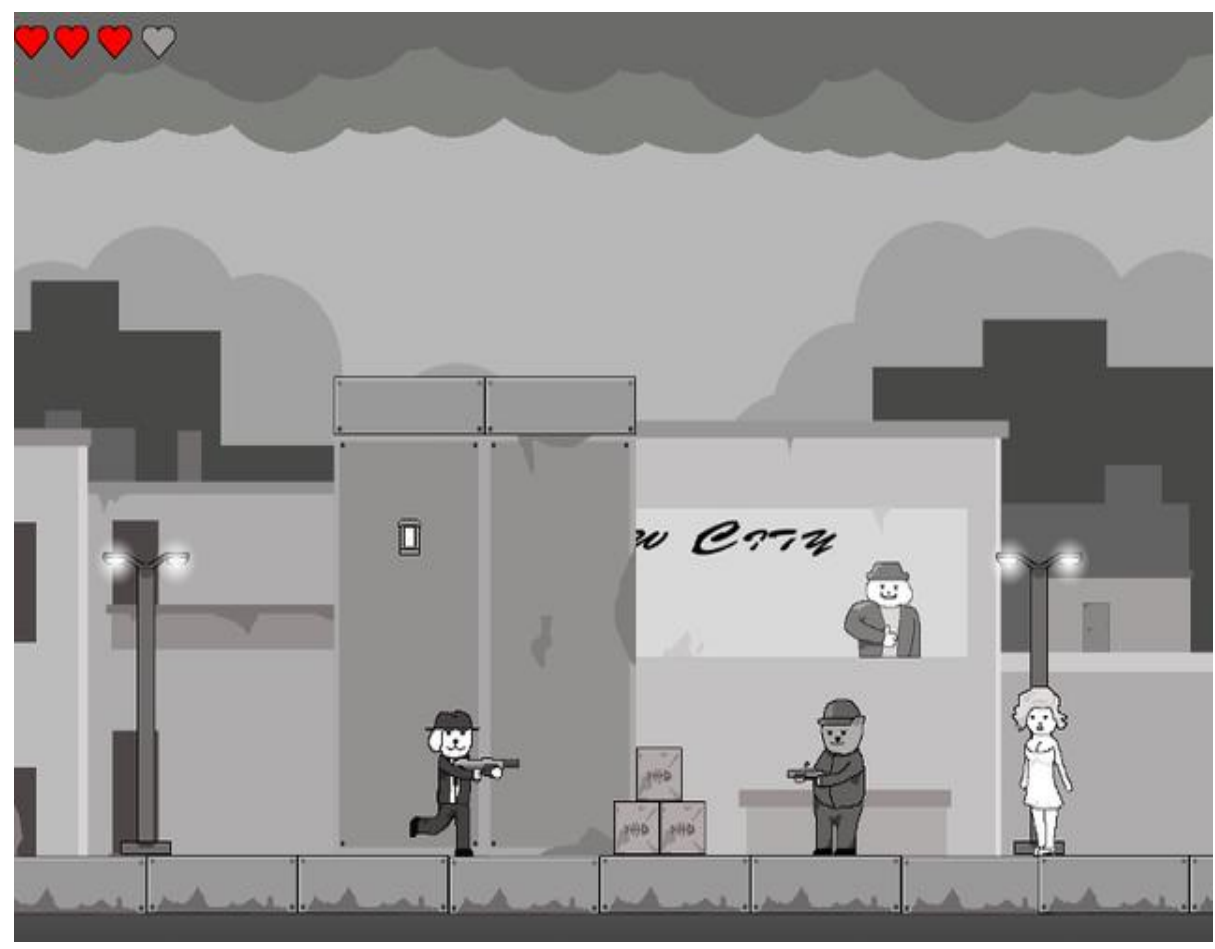

Źródło: http://innpoland.pl/117419,polacy-projektuja-gry-dla-niepelnosprawnychto-moze-wydac-sie-banalne-ale-widzimy-w-tym-sens (stan na dzień: 08.12.2016 r.)

Przyszłością rynku gier są smartfony, na które powstaje coraz więcej aplikacji służących do rozrywki. Nie zawsze dorównują one tym wydawanym na komputery stacjonarne, ale często przebijają je popularnością. Jednak brakuje pozycji wśród aplikacji mobilnych, które byłyby dostępne dla osób niepełnosprawnych. Polacy starają się to zmienić, dlatego też stworzyli grę, która służy głównie rozrywce. 
Studenci Akademii Finansów i Biznesu Vistula zaprojektowali pierwszą mobilną grę, która jest dostosowana do potrzeb osób niepełnosprawnych ruchowo.

Gra Mafia: Settle in Chicago jest prostą platformówką wzorowaną na czarno-białych filmach o gangsterach i grach 8-bitowych. Akcja osadzona jest w latach '60, główny bohater musi zmierzyć się z wrogim gangiem. Jednak ważniejsze niż fabuła jest to, że od początku projektowano grę z myślą o zazwyczaj pomijanej części społeczeństwa.

Największym wyzwaniem w trakcie procesu tworzenia gry było wymyślenie wszystkich ułatwień, dzięki którym jak najwięcej osób będzie mogło korzystać z aplikacji. Poza możliwością konfiguracji sterowania twórcy wprowadzili także opcję zmiany kontrastu kolorów. Dzięki temu mogą grać także osoby słabo widzące.

Obecnie nad grą wciąż trwają prace i zbierane są fundusze nad jej dalszym rozwojem. Za pomocą portalu crowdfundingowego polakpotrafi.pl każdy może się dołożyć do projektu. Cel zbiórki wyznaczono na 12 tys. zł. ${ }^{44}$

\section{Podsumowanie}

Polscy deweloperzy i autorzy gier komputerowych bardzo różnie podchodzą do uwzględnienia potrzeb graczy z niepełnosprawnościami. Widać jednak, że kwestia dostosowania gier do możliwości osób z rozmaitymi typami niesprawności zaczyna się przebijać do świadomości rodzimych twórców. Ogólny obraz jest bardziej optymistyczny niż można było spodziewać jeszcze kilka lat temu, co nie znaczy, że jest idealnie. Warto by polskie firmy popracowały nad wdra-

$44 \quad$ Źródło: $\quad$ http://innpoland.pl/117419,polacy-projektuja-gry-dlaniepelnosprawnych-to-moze-wydac-sie-banalne-ale-widzimy-w-tym-sens (stan na dzień: 08.12.2016 r.) 
żaniem ułatwień dla graczy niepełnosprawnych, bo z jednej strony dzięki temu mogą zyskać dużą grupę wdzięcznych klientów, a z drugiej - więcej osób będzie mogło cieszyć się przygodami w wirtualnych światach, na przekór barierom jakie napotykają w codziennym życiu.

\section{Bibliografia}

1. http://dziendobry.tvn.pl/wideo,2064,n/gry-komputerowe-pomoganiepelnosprawnym, 48476.html.

2. http://www.inter.uni.lodz.pl/index.php/media/209-wirtualne-gryrealne-korzyci.

3. http://www.psxextreme.info/topic/109036-gry-dla-os\%C3\%B3bniepe $\%$ C5\%82nosprawnych/.

4. http://www.kson.pl/gazeta/na-swiecie-i-w-kraju/611-grykomputerowe-dla-niepelnosprawnych.

5. http://www.includification.com/.

6. http://www.kson.pl/gazeta/na-swiecie-i-w-kraju/611-grykomputerowe-dla-niepelnosprawnych.

7. http://www.unstoppablegamer.com/pokemon-sun-and-moon/.

8. http://www.unstoppablegamer.com/tag/one-handed/.

9. http://www.niepelnosprawni.pl/ledge/x/11474.

10. http://www.inter.uni.lodz.pl/index.php/media/209-wirtualne-gryrealne-korzyci.

11. https://en.wikipedia.org/wiki/Video_game_rehabilitation.

12. https://www.youtube.com/watch?v=CCvBevd_Xvc.

13. http://www.mirarehab.com/.

14. http://www.virtualrehab.info/.

15. https://www.youtube.com/watch?v=2XNX_tZHL2E.

16. http://innpoland.pl/117419,polacy-projektuja-gry-dlaniepelnosprawnych-to-moze-wydac-sie-banalne-ale-widzimy-w-tymsens. 
